Est Ag 44 (2009) 61-86

\title{
The Life and Work of Raimon Panikkar, an ambassador of culture and civilization of India*
}

Thank you for having invited me to talk on the life and works of Raimon Panikkar. It is an honour and at the same time a challenge; for Panikkar is admittedly a daunting figure. His thought covers various disciplines, like philosophy, religion, science, politics, etc. and geographical regions like Asia, Europe, America, and so on. It extends to various centuries of human thought, and tries to present them all in a synthetic manner often making use of neologisms. The depth, extent and complexity of Panikkar's thought offers a challenge to anyone who intends to present it adequately to an audience. Hence, the scope of this talk is modest: it offers an introduction to Panikkar's intuitions, indicates some of its central aspects and signals the sources wherefrom the basic notions originate.

Although interest in Panikkar has been steadily increasing, and his thought has been presented from various perspectives, it does not constitute a system. In his own words, it aims at an integration of reality, allowing nothing to be left aside. Hence the interest in 'collecting the leftovers' -in gathering up the fragments-, that remain of human experience over millennia so that nothing be $\operatorname{lost}^{1}$. In order to do some justice to the multifarious nature of Panikkar's thought I shall be proposing an anthropological perspective. This for two reasons: first of all, it enables us to relate easily with his pattern of thought and second it would serve as an adequate introduction to most of the topics dealt with during the more than half a century of scholarship. Let me hence indicate the outline of this talk.

\footnotetext{
* Based on a talk given to the Canadian-Indian Friendship Society, Ottawa, on $8^{\text {th }}$ June 2008.

${ }^{1}$ Colligite fragmenta-Gather up the fragments-(Jn. 7,12), is the title given to the first part of his important work, The Cosmotheandric Experience, Maryknoll, New York: Orbis, 1993. One may also consider The Vedic Experience (Mantramañjarai. An Anthology of the Vedas for Modern Man and Contemporary Celebration edited and translated with introductions and notes by Raimundo Panikkar with the collaboration of N. Shanta, M. Rogers, B. Bäumer, M. Bidoli. Third Indian Edition. Delhi: Motilal Banarsidass, 1994 [1977]) as another example of this literary gender.
} 
The introduction serves to highlight the central topics of Panikkar's thought, link it to the anthropological perspective and lead to the cosmotheandric vision - the foundation of all his critique and innovatory proposals (I). Its impact on religious, philosophical and political realms is dealt with in the two following sections: Interconnected universes and religions -Pluralism as an attitude (II) and Plenitude of Man- a universal goal: cosmic confidence (III). The conclusion calls attention to a source, namely the Renaissance, not often discussed in studies on his thought. Intended or not, Panikkar's vision touches India in a special way, and the challenge it poses points directly to the transformation this country is currently undergoing. Hence Panikkar becomes a voice to be listened to.

\section{Introduction: an overview of Panikkar's life}

Among the contemporary scholars of Hinduism, Oriental Religions or Religious Studies, Raimon Panikkar occupies an admirable position especially for his decidedly holistic approach to what he calls the 'resource of human spirituality': that is India ${ }^{2}$. Panikkar's admiration for India as well as his connections to it is manifold: not only its culture, religion and civilization are things which matter him most, but also his own parental lineage. Panikkar is literally a person of 'double belonging' -a term initially used in connection with synchronic double, and later multiple, religious affiliations- not only from a biological but also religious/intellectual perspective. The latter does not often astound us, for intellectuals usually are considered to be persons with multiple abodes; but the combination of both in a single person is quite rare, and that is, has been, Panikkar. Let me hence trace this particular cha-

\footnotetext{
${ }^{2}$ Panikkar writes : « ici en Inde, on trouve l'humanité telle qu'elle est, sans les transformations que la civilisation -surtout la civilisation technique- a fait subir à l'essence même de la nature humaine; on rencontre l'humanité telle qu'elle vécu durant des milliers et des milliers d'années, et l'on découvre ainsi les valeurs primordiales de la vie de l'homme sur terre, valeurs qui ne consistent pas en des acquisitions culturelles mais dans le seul fait d'exister en tant qu'homme. L'humanité entière est là, elle vit une vie en prise directe, sans retour sur elle-même, comme une créature parmi les autres, la plus élevée -bien qu'elle ne le sache pas assez, bien souvent-mais créature en fin de compte participant à la création universelle. Le sens profond et dernier de la vie humaine est dans sa simple et nue existence -pour Dieu- et non exclusivement dans ce que l'homme pense de lui-même. La vie, même pensante, n'est pas seulement auto-reflexion rationnelle. La vie humaine est certainement une vie charnelle, mais d'une chair déjà en voie de résurrection et pas seulement animée par une âme rationnelle », Lettre sur l'inde, (Tournai, Belgique: Casterman, 1963).
} 
racteristic of Panikkar as a person and a thinker before we broach on any aspect of his unique approach towards India as well as to religion in general.

Despite the scarcity of information about Panikkar's personal life, we do know that his parents were of Keralite and Catalan origin ${ }^{3}$. Kerala and Catalonia are two regions of Asia and Europe, India and Spain respectively, with distinctive cultural and religious underpinnings. The orthodox Hinduism represented by Kerala (hence "mad house" for Vivekananda) and the Roman Catholicism rooted in Catalonia do find a significant place in Panikkar's life and thought.

As a child of Indian and Catalan/Spanish parents, Panikkar can claim that he belongs both to India and Catalan-Spain. Panikkar's biological and intellectual identity seems to have undergone various phases of development. He acknowledges that it was his father who introduced him to Hinduism. But he acquired a thorough knowledge of Sanskrit under the famous Mallorcan scholar Joan Mascaró who later became a professor at Cambridge and translated the Dhammapada and Bhagavad Gita into English. Similarly with regard to Christianity he was instructed in his mother's Catholic faith, under the Jesuits in Barcelona, continued his studies in Philosophy at the University of Bonn during the Spanish Civil War (1936-39) thanks to the British Passport he held. But could not anymore return there due to the start of Second World War, and became associated with José María Escrivá de Balaguer (1902-1975), the founder of Opus Dei, a conservative but socio-intellectual catholic movement politically and socially still very influential in Spain and elsewhere. This involvement with the Opus Dei constitutes an important part of Panikkar's life, especially in his academic development and political perspectives.

In 1941 Panikkar graduated in Chemical Sciences from the University of Barcelona, and in 1942 in Philosophy from the University of Madrid, and began working as an assistant manager at a chemical factory (most probably owned by his father); he later became the official representative of a group of industrialists to the Spanish government, and continued his post-graduate studies as well as worked as tutor at the Psychology Institute of the University. Further Panikkar was involved since 1942 with the High Council of Scientific Research (Consejo Superior de Investigaciones Científicas), mostly in the hands of the Opus Dei members or associates. As an influential member of the delegation of this central governmental organization at Barcelona,

\footnotetext{
${ }^{3}$ His father Ramunni Panikkar was a freedom fighter, went to England to study Chemical Engineering, since 1916 worked in Barcelona as representative of a German leather firm. There he settled down as an industrialist and married Carmen Alemany, a well-educated Catalan.
} 
Panikkar was able together with others to start a journal -Sintesis- in 1943, which in 1944 under the name Arbor became the official organ of the CSIC.

His first doctorate ${ }^{4}$ was a study on the concept of nature, a topic also dealt with by the Spanish intellectual Xavier Zubiri (1898-1983). This as well as his earlier writings shows a concern for synthesis, integrating metaphysical questions with theology and science. The interdisciplinary tendency would continue all throughout his intellectual career. However, the topic studied by Panikkar was treated under the title 'Christian philosophy'. This in turn provokes the issue of the supernatural, human nature and nature in general in contrast to culture. Panikkar's concern for culture goes thus back to his first doctorate, and is a response to the intellectual climate existed in the Europe of that time.

Being still a member of the Opus Dei, Panikkar was ordained priest in 1946, assumed a teaching career at Complutense (1946-53) ${ }^{5}$.

Panikkar's encounter with India begins with the year 1954, as Senior Research Fellow at the Universities of Mysore and Varanasi. However, what occasioned it was a rift with the Opus. Although Panikkar himself does not tell us much of this, credible sources indicate that his critical attitude towards contemporary Christian Theologians such as Karl Rahner, Karl Barth, Oscar Cullman and intellectuals such as Romano Guardini, Joseph Pieper, etc., and open criticism of Christianity angered the superiors, who eventually asked him to do theology in Rome. Thus in 1954 he graduated in Theology, visited briefly India -perhaps also inspired by the missionary Enrique Heras S.J., a good acquaintance of the family-, still maintaining his ties with the organization. From 1955 onwards he prolonged his stay in India, although was often absent from the country for various reasons. And continued to keep up the relationships he already built up with Jacques-Albert Cuttat (1909-1989), the Swiss ambassador to India; the French Benedictines Henri Le Saux (Abhishiktananda, 1910-1973) Jules Monchanin (Parama Arubi Anandam 18951957); and the English Benedictine Bede Griffiths (1906-1993, Swami Dayananda), under whom he refined his Sanskrit. The last three mentioned were pioneers in the emerging dialogue with Hinduism.

In 1958 Panikkar obtained a second doctorate now in Science ${ }^{6}$ from the University of Madrid. The relationship between science and reason would

\footnotetext{
${ }^{4}$ The dissertation in philosophy was presented to the Complutense University of Madrid in 1945, and was published in 1951 (Madrid: CSIC) under the title: El concepto de naturaleza: Análisis histórico y metafísico de un concepto.

${ }^{5}$ He celebrated the diamond jubilee of his ordination on $29^{\text {th }}$ September 1996.

${ }^{6}$ Ontonomía de la ciencia: Sobre el sentido de la ciencia y sus relaciones con la filosofía, Madrid: Gredos, 1961.
} 
constitute a central concern for Panikkar especially since his encounter with India. For the spirit of colonialism and the current supremacy of technology, demonstrate, according to him, the unilateral conception of world problems. Monocultures and rationalistic solutions do not lead to the betterment of humanity. This is a perspective, argues Panikker, supported also by the Indian thought as well as other age-old philosophies.

In 1959 he was one of the three delegates to welcome XIV Dalai Lama in his exile to India, and they spent considerable time together at the Himalayan Buddhist monastery of Rumtek. Panikkar also held the Festrede -laudatio- at Dalai Lama's 60 ${ }^{\text {th }}$ anniversary on $6^{\text {th }}$ July 1995; the talk was on the topic Time and Transcendence.

For three years from 1960-63 he lived in Rome as professor of Sociology of Religion both at the International University of Social Sciences (Pro-Deo) and at the Roman State University. This was the occasion for him to experience at first hand the developments of Vatican II. Panikkar's influence is noticeable in the liturgy commission under Cardinal Giacomo Lercaro of Milan which brought up the argument that gospel should not be presented under the mantel of a single culture. Henceforth Hinduism becomes his principal concern, and the first important academic result was the now famous book: The Unknown Christ of Hinduism, part of which (the last 2 chapters) was presented in 1961 as his doctoral thesis in theology at the Lateran University, Rome.

In 1964 Panikkar went back to India; in 1965 and in 1974 he was asked by the Government of India (Department of Cultural Affairs) to lecture in Latin America on Indian philosophy, culture and religion. In 1966 he represented UNESCO at the Oriental Studies colloquium in Buenos Aires. In India Panikkar was a collaborator at the Institute for the Study of Religion and Society in Bangalore, under the directorship of M. M. Thomas (19161995), who in the 90's became for a short time the governor of Nagaland and Arunachal Pradesh. Panikkar also lectured at the Universities of Varanasi and Mysore. All these point to his involvement with the Indian Elite; but he was also among the common people especially as a pilgrim, and in the company of the Benedictine monk Abhishiktananda. Panikkar considered this pilgrimage as a ritual ceremony in Vedic spirit. Officially he was incardinated to the Roman Catholic diocese of Varanasi. However, the discovery of India has begun to change his life in various ways. Outwardly it showed in the surname he used: it wasn't any more Pániker, but Panikkar.In an interview given in German he tells us: I did not go to India, my land of origin, as a teacher, but as a student; not as someone who is already a scholar, but as a seeker. I sat without any difficulty at the feet of the master, learned the language of the people and was one among them. It was not pre-planned. It was my $\mathrm{karma}^{7}$. 
Around this time he also left (or was expelled from) the Opus Dei. According to some, he was held captive in an Opus Dei house in Rome, and was released under the behest of Paul VI, with a one-way ticket to India. Interestingly Panikkar was not Christian enough for the Opus, but was too Christian for the Benares Hindu University to offer him a professorship!

Thereafter follow visiting Professorship at Harvard $(1967-1971)^{8}$, at the University of Montréal (1968), and Professorship at the University of California at Santa Barbara (1971-85) ${ }^{9}$. Besides participating in international symposiums -e.g. held by Enrico Castelli on Hermeneutic and Demythologization-, Panikkar was also in the editorial boards of many scholarly journals, such as: Journal of Ecumenical Studies, Jeevadhara, The Journal of Dharma, Concilium, Classics of Western Spirituality, etc. But he continued to visit India for lectures and conferences. Most of his cross-cultural studies and books on Indian culture and civilization belong to this period. In discussing his thought, we shall be referring to some of these texts.

Since 1986, Panikkar has retired from teaching and established himself in Tavertet, Catalonia; and continues his cultural involvement as much as the age permits.

A few remarks seem opportune before we move on to the next topic:

First: The impact of the biological lineage and the institutional associations was quite noteworthy in Panikkar's thought. For he writes: "Our first task is to understand ourselves, to strive to become intelligible synthesis not necessarily a system. Experience is paramount, life has the priority, praxis always leads. Our life is the foundation of all our thoughts" ${ }^{10}$. We shall come back to this issue of identity at a later stage, from a different perspective.

Second, however factual and hence significant this biological link is, Panikkar holds his symbolic relationships at a higher esteem. That is to say, he prefers not only to define himself as a global citizen, but more often as a religious person simultaneously at home with Christianity (better Roman Catholicism), Hinduism, Buddhism and secularism. In a text dealing with in-

7 "Ich ging nicht als Lehrer nach Indien, meninem Herkunftsland, sondern als Schüler, nicht als jemand, der schon einiges studiert hatte, sondern als Suchender, als jemand, der ohne Schwierigkeiten zu Füßen eines Meisters saß, die Sprache der Einheimischen lernte (und das schlect) und einfach einer unter vielen war. Das war ganz offensichtlich keine Taktik, ich hatte es auch nicht vornherein so geplant. Es war mein Karma,, Pinchas Lapide u. Raimon Panikkar, Meinen Wir denselben Gott? München: Kösel Verlag, 1994, p. 177.

${ }^{8}$ Visiting Professor of Comparative Religion, at the Centre for the Study of World Religions directed by Wilfred Cantwell Smith.

9 Panikkar held the Chair of Comparative Philosophy of Religion and History of Religions

10 Joseph Prabhu (ed.), The Intercultural Challenge of Raimon Panikkar, Maryknoll, New York: Orbis, 1996, p. 241. 
terreligious dialogue, Panikkar writes: "I "left" [1954] as a Christian, I "found" myself as a Hindu and I "return" a Buddhist, without having ceased to be a Christian"11. And again in another text Panikkar explains this multiple religious belonging as follows: "Personally I have discovered secularity after having experienced to the full, I would dare to say, the most severe Roman Catholic tradition. And I have discovered Buddhism after having plunged into the most strict vedántic orthodoxy. [...] In a word, my Christian identity has led me to understand and accept what I call secularity. And my Hindu identity has equally conducted me to the an tman insight, or rather to the "non-experience"of the an tmav da [...]"12.

Panikkar is hence, in his own words, a Christian-Hindu-Buddhistsecularist - all at the same time without admixture. The different colours or layers of his identity are visible, active and co-existent in the same person. This self-understanding is already a challenge for anyone to comprehend Panikkar's intellectual pursuits, especially his conceptions of religion and the goal of human life. Again we shall take up the point later in some detail.

But let me mention also another daunting challenge in dealing with Panikkar's writings. To the outside world, Panikkar is an intellectual, a polyglot and above all a scholar of religions/cultures, but he is also someone who combines the theory in a very practical manner, so that theorein -the theorizing- becomes a life-style: an intellectual pattern already known and practiced in the ancient Greece, as well as in Rome, even during the time of Augustine. Especially in the West, this life-style has become a model for monasticism or mysticism. And we do discover here strong links with the Classical Hindu hermitage: the life of the Yogis, praised by the Vedas and Kalidasa. Hence, when Panikkar refers to himself as a seeker of wisdom, or when his perspectives regarding other religions are taken to be 'mystical pluralism', he does approve of it, but at the same time emphasizes that he is a yogi, monk, arhat and a humanist - all at the same time. This is what is meant, when Panikkar talks of himself as a monk ${ }^{13}$.

Biological double belonging, religious and cultural multiple belonging characterize Panikkar as a person. Even his name testifies to it: Raimundo, Raymond, Raymondo and Raimon. No single adjective describes him ade-

${ }_{12}^{11}$ Raimon Panikkar, The Intrareligious Dialogue, New York: Paulist Press, 1978, p.2

12 J. Prabhu, The Intercultural Challenge of Raimon Panikkar, pp. 256-66

13 "Since my early youth I have seen myself as a monk, but one without a monastery, or at least without walls other than those of the entire planet. And even these, it seems to me, had to be transcended -probably by immanence- without a habit, or at least without vestments other than those worn by the human family. Yet even these vestments had to be discarded because all cultural clothes are only partial revelations of what they conceal; the pure nakedness of total 
quately, except perhaps the demonic term: legion. And daemonic -in its literal sense daimonion - is Panikkar's thought: creative and dynamic. Consequently, his thought can and need be related to patterns of thought spanning various centuries (saecula), and I shall attempt to point out solely two of those: the archaic and the renascent. Both these aspects would take us to the religious cultural complex which mainly constitutes Panikkar's thought. Let me hence introduce the archaic, for it acts as the springboard to the first central part of his philosophical vision. And I will come back to the renaissance aspect, later in the conclusion.

\section{Cosmotheandrism: awareness of the triadic nature of reality}

Cosmotheandrism constitutes the foundation of all Panikkar's thought. Although it has been inadvertently present in his writings from the very beginning, it was clearly spelt out in the 80 's, and was first presented in detail in 1993 with the publication of The Cosmotheandric experience-emerging religious consciousness. We shall approach the topic through a myth.

Here is a myth from Mozambique: Early in the morning the fisherman went out to fish at the big river that flows into the sea. From dawn to dusk he worked hard, and had a good catch for the day. At day's end he gathered all the fish he caught in three baskets, placed them on his head and walked back home. In order to reach the home, he had to pass through a forest inhabited by wild animals. On the way, he was met by a crocodile which friendly greeted him: 'Good day, Sir". The fisherman did not respond, and sped up in the direction of his village. The day after he was summoned by the village chief, for the crocodile has complained that the man has behaved impolitely. Asked to explain himself for this rude behaviour, the man responded as follows: 'I had with me only three baskets full of fish. One was destined to my wife, the other to my children and the third to my parents. I did not have anything more, and hence I did not respond to the crocodile'. The chief and his council pronounced him right. For, he conducted himself like a man, which was expected of him. And also the crocodile agreed to the judgement of the village council.

transparency only visible to the simple eye of the pure in heart ... By monk, monachus, I understand that person who aspires to reach the ultimate goal of life with all his being by renouncing all that is not necessary to it," Blessed Simplicity: The Monk as universal Archetype, New York: The Seabury Press, 1982, pp. 6 \& 10. 
This is of course a myth describing an event taking place at a time when humans and animals live together in harmony and understand each other. According to the native interpretation, the myth describes the relationship and responsibility of the human person: the net-work of relations around him. The fisherman's first relation and responsibility is towards his wife with whom he shares his life; it is a relationship of mutuality: argumentative, understanding, etc. We may call it predominantly dialectical relationality. The second relation and responsibility is towards his children. Although from an anthropological perspective it is a relationship of mutuality, it entails a special kind of responsibility on the part of the parent, for the simple reason that the children continue the human species, and are also dependent on the parent in order to be empowered to realize the role corresponding to them. We may call it essentially a dialogical relationality, which does not exclude the dialectical. The third relation and responsibility described in the myth is towards the parents of the fisherman. It again has the characteristic of mutuality, but goes beyond it, in as much as it is incommensurable relationality. Incommensurability is posited, for the fisherman has received his life gratuitously from the parents. He cannot at all compensate them for that gift, for example, by giving life back to the parents. That is to say, he cannot be the parent of his parents. Here again, dialectical and dialogical aspects are present, alike the aspects of incommensurability and dialogue form part of the first type of relationality.

The three kinds of relationality mentioned here, dialectical, dialogical and incommensurable are necessary to live the life as a human person. They are required in different measures in our relation with the world, the nature and the divine. Further according to the myth, these relations also represent the human person's responsibility to the three generations he/she deals with: namely the present, future and past generations. The responsibilities and relations may have much in common, but are also distinct with regard to each generation. That is to say, a specific relationality may be predominant with regard to the past generation, but this does not exclude the presence and necessity of the other types of relationality even in this sphere. The myth thus situates the human person in the universe he/she lives in. It centres him/her in the world and orients him/her in life by providing an awareness of reality.

What has this mythical awareness to do with Panikkar's cosmotheandric vision? First of all, the cosmotheandrism proposed by Panikkar highlights the interrelationship between the three dimensions all of which together constitute the reality. This reality as such includes the various awareness of it presented in the cultures of the world. These visions may be seen as pars pro toto, e.g., as a drop of water stands for the ocean. Secondly, the cos- 
motheandrism affirms that the essential structure of reality is triadic; and this fact is demonstrated by the various religions. Thirdly, cosmotheandrism is an awareness of reality, or in other words, more than a viable hypothesis, not a rational proposition to be demonstrated. It hence suggests and invokes the vision, does not impose it, or rationally proves it.

How does Panikkar then explain the cosmotheandric vision? In one of the first descriptions of it, Panikkar calls cosmotheandrism an intuition, and affirms: "The cosmotheandric awareness might well be considered the primordial form of consciousness". His point is that it is "an invariant of human culture", and hence expressed variously in various cultures: "There is a world of the Gods, another of Men and a third of material things; there is Heaven, Earth and the Underworld; there is the sky, the earth and in between; there is the past, the present and the future; there is the ontological, the psychical and the corporal, etc."14. It is hence an intuition of the whole, a synthetic vision. This holistic intuition has been part and parcel of humanity, as the myth we just cited illustrates; but it has been forgotten, or left over. Panikkar hence attempts to re-integrate this vision with the other current world-views. $\mathrm{Co}$ lligite fragmenta.

This holistic vision of reality comprises of three dimensions. The term dimension is employed in order to highlight the intrinsic relationship between these, without cancelling out their distinctiveness. Hence Panikkar would argue that the three dimensional reality is marked by 'radical relativity' - a term which emphasizes the inevitable interdependence of the aforementioned dimensions. These dimensions are understood as metaphysical (transcendent, apophatic); noetic (conscious or thinking), and empirical (physical or material). In other words, Panikkar's cosmotheandrism affirms that "the divine, the human and the earthly ... are three irreducible dimensions which constitute the real, i.e., that is any reality insofar as it is real. Everything that exists presents this triune constitution expressed in three dimensions"15.

The last sentence of this quote needs attention. For the cosmotheandric intuition does not divide reality into three, but affirms that everything possesses these three dimensions. Hence it would be unacceptable, for example, to speak of the divine without indicating the human and earthly dimensions present in it, and vice versa. The challenge consists in explaining how the distinct dimensions are present in each other. Let us follow Panikkar's explanation, as he starts with the divine.

\footnotetext{
14 “The Cosmotheandric Intuition," Jeevadhara 14 (1984) p. 27.

15 "The Cosmotheandric Intuition," Jeevadhara 14 (1984) p. 29.
} 
Theos, the dimension of the divine: For Panikkar every being is both transcendent and immanent. It transcends itself and is unfathomable. "The basic perception here is the infinite inexhaustibility of any real being, its everopen character, its mystery". Anything and everything that exists, that is real, we may say, is indestructible in its totality. And this dimension is not anything superimposed on being, it is part of it; it is a constitutive principle of things. The divine dimension cannot be written off, or attributed to a realm of its own in any absolute sense. For absolute transcendence would be a contradiction. With regard to Man -anthropos- this dimension is evident in his possibilities: the human can become ever more. "This ever more ... stands for the divine dimension" "The depth of Man's being is infinite. Following this argument, and applying it now to the world -Cosmos-, Panikkar would argue that the divine is that dimension of more and better for the World as much as for man. Neither man, nor the cosmos is a finished product; they are in expansion which indicates the divine dimension built in them.

In describing the second dimension, namely anthropos, Panikkar notes that Man is not the isolated individual, but a person "with the sky above, the earth below, and his fellow-beings all around" 17 . However, the characteristic aspect of this dimension consists in consciousness: first of all, every being is linked to it; that means, it is thinkable, hence connected to human awareness. The fact that the reality is thought by Man, argues Panikkar, 'the entire field of reality lives humanized in him'. "This transparent character of consciousness belongs not only to the one who knows, but also to the object known." This is the human dimension, may also be called the dimension of consciousness, "for whatever consciousness may be, it is manifested in and through Man".

Following the hypothesis introduced at the beginning, Panikkar argues that the three dimensions of the reality are not mutually reducible. So the material world and the divine aspect are irreducible to consciousness. Yet both are pervaded by and co-extensive with consciousness. This makes reality knowable, and hence we need say that it is a constitutive dimension of reality.

Cosmos is the third dimension of reality. And this refers to the constitutive relationship of anything existing to the world of matter or energy and of secularity, namely space and time. Materiality and temporality, we may say, indicate the cosmic dimension constitutive of reality. When Panikkar speaks here of Cosmos or World (written with Capital), he is not referring to the habitat or an external part of the whole, but to the greater body of which one

16 "The Cosmotheandric Intuition," Jeevadhara 14 (1984) p. 30.

17 "The Cosmotheandric Intuition," Jeevadhara 14 (1984) p. 31. 
is only imperfectly aware. For: "The Cosmos is not just matter and convertible energy; the Cosmos has life and, like Man, a dimension of plus, a share in the divine dynamism. I am saying that there are no disembodied souls or disincarnated Gods, just as there is no matter, no energy, no-spatio temporal world without divine and conscious dimensions. A purely immaterial being is as much an abstraction as an exclusively material one; ... the ultimate basis for Man's hope cannot be severed from the existence of the World"18.

In brief, what Panikkar proposes is "a wholistic and integral insight into the nature of all that there is" 19 . In simpler terms we may say that the cosmotheandric vision highlights the inseparable interdependence of nature, humans and the divine, which according to Panikkar (has been and) is being ignored by Western patterns of thought and praxis. For the concept of inert matter, emphasis on reason and the unwarranted confidence set on technology, have widened the gap between humans, humans and the nature, called into question the human fulfilment envisaged by various cultures. This western pattern of thought promotes rationalism, blindly believes in technique and eventually destroys the nature which sustains all our life. Since this is a highly selective and inherently destructive pattern of thought, one has the obligation to re-discover the wisdom of humanity. One of its sources is India, which (among others) also provided Panikkar with the inspiration to propose the cosmotheandric vision. We shall now move on to the sources of this vision, concentrating especially on India and Panikkar's pluralism.

\section{Interconnected universes and religions: Pluralism as an attitude}

Panikkar admits openly that the proposed cosmotheandric vision is based on the religious insights of humanity; especially three perspectives are abundantly quoted in his writings: Christian, Hindu and Buddhist. Without examining or describing them in detail, I would like in this section to present a few comments with regard to the Hindu resources he makes use of. For this would enable us to comprehend what he proposes as pluralism and advocates as the model for humanity, especially for India as it emerges into a powerful democracy.

\footnotetext{
18 "The Cosmotheandric Intuition," Jeevadhara 14 (1984) p. 33.

19 "The Cosmotheandric Intuition," Jeevadhara 14 (1984) p. 34.
} 
According to Panikkar, the cosmotheandric vision corresponds to and is founded on "the Christian understanding of Trinity, the hindu notion of advaita, and the Buddhist prat tyasamutp da"20. This statement refers mainly with regard to Hinduism to a study, published in 1970, on The Trinity and World Religions, where Christianity and Hinduism are interpreted as two different but interrelated spiritualities.

At least three points are of interest to us: First, Panikkar reminds us that often our understanding of religion is very restricted, for we identify it with its sociological manifestation, whereas it is also doctrinal, sacramental and mystic. We may hence, for example, speak of the Christian religion as Christianity / Christendom from the sociological and political perspective or as Christian faith from a doctrinal-sacramental level or as Christianness from a mystical view-point. The one-dimensional description of religion is the result of rationalistic-scientific thought, which does not promote a holistic approach. Adopting a holistic approach, one should better speak of religion as spirituality. Spirituality is here understood as "one typical way of handling the human condition; ... it represents man's basic attitude vis-à-vis his ultimate end. One religion, in fact, may include several spiritualities, because spirituality is not directly bound up with any dogma or institution. It is rather an attitude of mind in which one may discern various component parts"21.

With this understanding of religion as a conglomerate of spiritualities, Panikkar would propose a three-fold classification of religions, which he calls religion 1 , religion 2 and religion 3 . Religion 1 corresponds to the socio-cultural level, where one may even consider them as 'equivalents', for they are 'historical facts'. Religion 2 corresponds to the doctrinal-sacramental level, where religions can be considered as mutually 'complimentary'. These two levels lead to religion 3, for the three dimensions mentioned are distinct but not separate. Hence Panikkar observes: "My approach to religion 3 is always limited depending on $\mathrm{r} 1$ and $\mathrm{r} 2$. So that I cannot say regarding religion 3 that it is one or many; there is neither one nor many. I see it in and through $\mathrm{r} 1$ and $\mathrm{r} 2$ reaching as far as $\mathrm{I}$ can $\mathrm{r} 3$. But I do not exhaust $\mathrm{r} 3$ at all ... I am not saying that we are saying the same thing with different names. First because $r 3$ cannot be properly described; and secondly, because I am not a nominalist, so that the name I give belongs to the thing in a certain way. This is one aspect which I do not know how it tallies with the other, but we are entering into that realm in which we can only babble up, totter and somewhat figure out. Yet the

\footnotetext{
20 "The Cosmotheandric Intuition," Jeevadhara 14 (1984) p. 28.

21 The Trinity and World Religions, Madras: The Christian Literature Society, 1970, p. 9.
} 
name is fundamental. Because this name is the way in which the religion 3 reveals itself to me"22.

Panikkar's stand is holistic, and hence does not separate religion 1 from religion 2 or from 3; they all belong together despite the distinctive characteristics of each. In order to accept this holistic approach, Panikkar observes, one needs "radical humility". For: "I cannot have access to $r 2$ and r3 if not through r1"23. Consequently, Panikkar does not call for an annihilation of the institutional or sacramental religion, but an integration of the three inseparable dimensions so that religion does not become a simple appellative or name-tag.

Our second observation concerns the Hindu-Christian spiritualities and their correspondences. In the study already mentioned, Panikkar interprets religion as consisting of three spiritualities, namely of action, love and knowledge. They can also be called iconolatry, personalism and mysticism. They do correspond to the triad r1, r2 and r 3 mentioned earlier, but are not identical. We need also bear in mind that these spiritualities are not separate but distinct; together they constitute the religion as an attitude to handle the human condition. In the first form of spirituality a person adopts "an image, an idol, an icon, which is at one and the same time outside (attracting), inside (inspiring), and above (directing)". It thus gives to the life of the person -that is to his moral character, his thought and aspirations- a proper orientation and stimulus for action" 24 . Here is a type of relationship established with regard to the absolute: one recognizes the transcendence and incommensurability, but establishes a link thanks to a form, an image or icon. The second kind of spirituality, personalism, corresponds to "an intimate personal relationship, by dialogue" with the absolute. "In this case", writes Panikkar, "God is the essential pole which not only orientates ... the human personality, but is also its constitutive element, for one cannot live or 'be' without love and one cannot love without that third dimension of verticality which is only realised in the discovery of the divine person" ${ }^{25}$. From the Christian perspective one recognizes here the so-called incarnational spirituality. "The third form of spirituality stresses the demands of thought and the exigencies of reason, or rather of the intellect or intuition; it rejects a God constructed more or less according to its own measure and its own needs and seeks to penetrate to the ultimate analysis of being and to find there a vision which enables man

\footnotetext{
22 "Man and Religion: a Dialogue with Panikkar," Jeevadhara 11 (1981) pp. 16-17.

23 "Man and Religion: a Dialogue with Panikkar," Jeevadhara 11 (1981) p. 19.

${ }_{25}^{24}$ The Trinity and World Religions, p. 10.

25 Ibid.
} 
to live while accepting to the full his own human-ness" ${ }^{26}$. The form of spirituality described here is what generally is known as mysticism. Despite being dependent on the other forms, this last one shows a kind of denial towards all the other forms of spirituality - a denial that is better described as an overcoming or transcendence.

Now Panikkar argues that if we take into account these different types of spiritualities which constitute the religion from a holistic perspective, we shall have a better idea of how religions -in our case Hinduism and Christianity- correspond mutually. Without going into details, let me briefly state Panikkar's argument.

According to him, the aforementioned three forms of spiritualities -namely of action, love and knowledge- are found in Hinduism. They correspond to the Karmam rga, Bhaktim rga and Jñanam rga. Karmam rga or iconolatry projects God under some form; it is in fact, "religious cosmo-anthropomorphism; ... and the idol stands for the homogeneity which subsists between God and his creature"27. And Panikkar affirms that a God who lacks any relationship of form with humanity cannot be possibly its God. Further in this stage there is a latent icon-experience and existential reverence expressed towards the transcendence. Severance of this relationship with the transcendence might corrupt this form of spirituality. But iconolatry is one of the basic forms of human religious consciousness. The iconic form of worship confirms the religious notion that Man is an image of God, the world is a divine vestige, and the presence of the absolute is always incarnation.

However the development of human religious consciousness finds iconolatry insufficient for it lacks mutuality or reciprocity: I - Thou relationship. This new dimension is provided in personalism or bhaktim rga according to which "our personal relationships with God ... constitute real religion". In contrast to iconolatry, in religious personalism, "obedience", for example, is not "blind submission, but the acknowledgement of God's right to command. Love is no longer irrational passion or unconscious ecstasy but mutual giving. Worship is no longer annihilation of the self before the Absolute but voluntary affirmation of his sovereignty. Sin is no longer cosmic transgression but a refusal to love" 28 . Further: "If the desire for incarnation characterises our first dimension of spirituality and if its temptation is false idolatry, the thirst for immanence is the driving force behind personalism and its great temptation is anthropomorphism"29. However, this spirituality also

\footnotetext{
${ }^{26}$ Ibid

${ }_{28}^{27}$ The Trinity and World Religions, p. 15.

${ }^{28}$ The Trinity and World Religions, p. 21.
} 
is insufficient, for reciprocity cannot be maintained if love or devotion causes the beloved to disappear.

Hence the third dimension of spirituality Jñanam rga which for Panikkar consists in advaita. In this level the radical relativity or better relationality is maintained between the transcendence and the devotee. The God is not reduced to a Thou. Panikkar writes: "The Upanisads indeed point to a religious attitude that is not founded upon faith in a God-Thou, or God-willsovereignty, but on the supra-rational experience of a 'Reality' which in some way 'inhales' us into himself. The God of the Upanisads does not speak; he is not Word. He inspires; he is Spirit.... [Hence in] the schema of the Upanisads the main place is not given to call/response nor to acceptance/refusal. The basic categories here are knowledge and ignorance. The Absolute is discovered in its own realisation, i.e. in the experience in which it is attained. This meeting is not situated on the level of dialogue. Dialogue is itself transcended. Even the idea of meeting no longer enters the picture, for we are transferred to the sphere of union" 30 .The third form or spirituality is hence practically indescribable, for it is the result of ek-static or direct attitude. This is referred to in the Mandukya Upanisad as the fourth state of consciousness, tur ya; it is an advaitic experience of the Reality ${ }^{31}$.

Thus, for Panikkar, there exists a correspondence between Hinduism and Christianity if we pursue the holistic perspective of religion as spirituality. This argument is taken further with regard to the concept of Trinity -Father, Son and Spirit-interpreted in terms of advaita, which relates the margas to specific Christian praxis. We need not enter into that aspect, but shall deal briefly with the methodology employed in these arguments. For it will take us directly to Panikkar's pluralism, another asset of his encounter with India. So our third comment concerns the unique method of argument.

Undoubtedly the cosmotheandric vision proposed by Panikkar is based on the notions of advaita and trinity. But do these notions warrant the proposed hypothesis? Or in other words, how is it to be understood the correspondence

${ }^{29}$ The Trinity and World Religions, p. 25.

30 The Trinity and World Religions, pp. 28-29.

${ }^{31}$ The concept of God present here is corroborated by the $G$ ta, IX.4-5: In Me all beings reside, but I do not reside in them; yet in Me beings do not reside. Behold my divine mystery! I support yet do not reside in beings; my Self is that causes beings to be. Whereas "dialogue, the prayer of praise and petition, along with love and fulfilment of the divine will, are the basic religious categories of personalism, the essential attitudes of advaita will consist rather in silence, abandonment, total conformity, absolute detachment. Advaitin spirituality rejects all anthropomorphism" The Trinity and World Religions, pp. 36-37. 
established between Hinduism and Christianity? They are to be seen, according to Panikkar, as homeomorphic equivalences. This neologism wants to tell us first of all that Hinduism and Christianity, for example, are not identical even if they have various elements or patterns of thought in common. One cannot and should not assimilate the other; they are distinct, and the distinctiveness of a religion or culture needs be maintained. The commonality they have need be treated as equivalent morphological aspects; one may hence speak of functional equivalence, for example. That is to say, both Christianity and Hinduism enable their corresponding followers to lead a meaningful life. In simpler terms: The various means of transportation, train, aeroplane, automobile, etc. are functionally equivalent, but distinct. What Panikkar wants to avoid by using this methodological choice is the often quoted statement: all religions are equal. Or in its refined form, one might say that apparently the religions are different, but if we go into the profound dimensions, in the depth, they are equal. This argument has been also part of the Indian tradition, very convincingly expressed in terms of the story, the frogs and the coloured waters ${ }^{32}$. Panikkar's point is that such a stand would essentially eliminate all distinctions, promote hegemony, and hinder any fruitful dialogue between religions, cultures, peoples, etc. Hence the homeomorphic equivalence is the methodology which brings out the commonalities between religions, cultures etc. without eliminating their differences. Why is it so important? The simplest answer is that each religion or culture formulates the issues under different frameworks, or to use Panikkar's terminology they are expressions on different mythical backgrounds. And each religious affirmation or cultural insight is fully meaningful only within this framework; hence the great effort one makes to defend one's own myth. We may further clarify the issue if we compare religions with languages. Although all languages enable communication, no language can be fully meaningful without its syntax, grammar, etc. which constitute its framework. Homeomorphic equivalence safeguards thus the distinctive identity of each religion and culture, enabling at the same time mutual exchange or communication. We shall see later that this methodological choice has important consequences both in the religiouscultural as well as in the socio-political spheres. It is also the foundation of Panikkar's pluralism; and it goes without saying that the homeomorphic equivalence is a methodological strategy inspired by advaita, which is for Panikkar "an independent and third possible experience of reality"33.

32 The story is also referred to as the three wells and the coloured frogs, attributed to Buddha.
${ }^{33}$ J. Prabhu, The Intercultural Challenge of Raimon Panikkar, p. 274 . 
What is then Panikkar's pluralism? First of all Panikkar acknowledges that there are various types of pluralisms, political, civil, psychological, ethical, intellectual, metaphysical, cultural, philosophical, etc. And the term is often used in reference to society to mean "a tolerant, open, and a more or less sophisticated stand which accepts or finds a place for diversity of life styles, doctrines or religions". Although this is "a positive value and an indispensable attitude", Panikkar's understanding of pluralism is more basic. It is for him a "fundamental human attitude: aptitudo, that for which I am aptus, fit" 34 . The Sanskrit root is ap, apta, apnoti, meaning reach, obtain, attain.

What does pluralism as a human attitude mean? It means the recognition of a radical relativity regarding all our existential dimensions, and the consequent corresponding praxis: radical relativity means interconnectedness not relativism. Hence we need consider our perspective of the world, nature and the divine, for example, as $a$ window through which we view the reality. "We all see through our respective windows. ... Pluralism does not claim to see through all the windows or to control all (or some) of them. Pluralism simply acknowledges the existence of other windows" ${ }^{\prime 3}$. In other words, pluralism as an attitude would not co-exist with any absolute claims.

This does not, however, mean that pluralism is uncritical. "Pluralism takes a critical attitude which does not see the absolute necessity ... of reducing everything to one single truth ... since every truth has its own field and boundaries. ... [Further:] The pluralistic attitude accepts the stance that reality may be of such a nature that nobody, no single human group to be sure can coherently claim to exhaust the universal range of the human experience. The "reason" is that reality may not be totally objectifiable, because we, the subjects, are also part of it" ${ }^{\text {"36 }}$. This affirmation by Panikkar shows that his pluralism is a consequence of the cosmotheandric vision discussed above. Hence the following definition: "pluralism [is] that fundamental human attitude which is critically aware both of the factual irreducibility (thus incompatibility) of different human systems purporting to render reality intelligible, and of the radical non-necessity of reducing reality to one single center of intelligibility, making thus unnecessary an absolute decision in favour of a particular human system with universal validity - or even one Supreme Being"37.

Two observations on the definition: first, pluralism as an attitude is a human awareness, hence part of all patterns of thought irrespective of religion

${ }_{35}^{34}$ J. Prabhu, The Intercultural Challenge of Raimon Panikkar, p. 250.

35 J. Prabhu, The Intercultural Challenge of Raimon Panikkar, p. 247.

${ }^{36}$ J. Prabhu, The Intercultural Challenge of Raimon Panikkar, pp. 250-51. 
and culture. Second, the criterion for criticism is the so-called cosmic confidence (see below). Pluralism hence demands the methodological approach of homeomorphic equivalence.

\section{Plenitude of Man - a universal goal: cosmic confidence}

The overview of Panikkar's life and selective aspects of his thought hitherto developed, has attempted to show that the cosmotheandric intuition, the understanding of religion as spirituality as well as the pluralism as a basic human attitude has Indic origins. It is in highlighting and interpreting them in a universalistic perspective that Panikkar becomes the ambassador of Indian culture and civilization. In doing so he has advocated the innovative method of homeomorphic equivalence as the most adequate methodology for cross-cultural studies. What these intuitions constitute in the socio-political realm is our next concern. I shall be discussing briefly Panikkar's critique of monoculture directed not alone to the West. Emerging economic giants like India seem uncritically to pursue the goals set by western patterns of thought. And this demonstrates not only a lack of self-critical reflection on the part of these countries but also the necessity to propose and pursue wider goals taking into account the interconnectedness of the triadic reality: cosmos, theos and anthropos. Under three headings we may present Panikkar's thoughts in this sphere.

Plenitude of Man: One of his mainly theological studies entitled Christophany published originally in Italian in 1999 carries a subtitle: the Fullness of Man. In discussing the issue, Panikkar comes back again to the cosmotheandric vision, and makes the point that these three dimensions the cosmic, the human and the divine are to be seen as human invariants constituting the reality. Francis d'Sa rightly points this out in the forword: "The cosmic is about the objectifiable dimension of reality; the human stresses the objectifying dimension; and the divine is the depth dimension that endows the objectifiable and the objectifying dimensions with a certain endlessness, a kind of infinity. Because of the depth dimension, neither the cosmic nor the human dimension has a limit" ${ }^{38}$. We have already indicated their irreducibility and interdependence. Panikkar saw this vision as the emerging religious consciousness

37 J. Prabhu, The Intercultural Challenge of Raimon Panikkar, p. 253. 
which revises the way we look at God, Man and World. Now the point that Panikkar makes in talking about these dimensions as human invariants as well as proposing the subtitle 'fullness of Man' is discussed in detail from a Christian perspective. "There exists in each of us a desire for fullness and life, for happiness and the infinite, for truth and beauty that goes beyond religious and cultural contingencies"39. The symbol of this fullness is Christ, in the Christian tradition. But it is also relevant from a Hindu, Buddhist, secular or any other perspective, for it concerns the fullness of Man (written with a capital M). Panikkar's point is subtle and belongs to the realm of mysticism or advaita. The following quotation may give us an insight:

When I refuse to be called 'a human being', or when I criticize evolutionistic thought, when I claim to be unique and, to that extent, unclassifiable, I am reacting against the invasion of the scientific mentality which tends to obscure one of the most central of all human experiences: being a unique divine icon of reality, constitutively united with the Source of everything, a microcosm that mirrors the entire macrocosm. In a word I am one with ... the infinite, beyond all comparison and never interchangeable. The I is not me. I am not the product of evolution, a speck of dust, or even mind in the midst of an immense universe. Man, the integrally concrete, real man, is not an item in a classification scheme: it is he who does the classifying ${ }^{40}$.

In simpler terms Man cannot be reduced to an assemblage of chemical energy, or even to historical records. "Are we certain that a historical biography and a reading of his writings are sufficient to reveal who S. Rajagopalachari really was ...?" 41 , asks Panikkar. "For the complete Man ... is that unique being, athirst for the infinite, is not himself until he reaches his destiny. Man is more than his "human" nature" 42 . Hence Panikkar would submit with the Rg-Veda X, 90, 2: Purusa evedam sarvam: Man is certainly all this ${ }^{43}$. And the cosmotheandric perspective ensures that the Fullness of Man remains the goal of humanity. It is with this foundational perspective that Panikkar engages with science, technology, progress and politics, and hence his comments would make sense only if we share or understand the holistic goal attributed to the human person who Panikkar adamantly refers to as Man (with a capital M), in order to emphasize that he rejects any reduced

38 Raimon Panikkar, Christophany. The Fullness of Man, Maryknoll, New York: Orbis Books, 2004, p. xii.

${ }^{39}$ R. Panikkar, Christophany, p. xx.

${ }^{40}$ R. Panikkar, Christophany, p.xvii.

${ }^{41}$ R. Pnikkar, Christophany, p. 158.

42 R. Panikkar, Christophany, p. xxi.

${ }^{43}$ R. Panikkar, Christophany, p. xix. This is the epithet for his preface. 
notion of the human person. Interconnectedness, interdependence as well as a call to infinity characterizes the Man; hence, Panikkar refers to him not only as microcosm, but also as mikrotheos. The consequences of this perspective are readily seen in the socio-political and eco-scientific realms.

Technology and cosmic confidence: Panikkar has been often criticized even by some of his best admirers for the lack of solidarity with the poor and the defence of ecology especially by the use of innovative technologies in his writings. Both these issues were clearly addressed in a volume honouring his $75^{\text {th }}$ anniversary of birth, but published on the jubilee of his priestly ordination on 29th September 1996. In his response Panikkar admits that he may be easily misunderstood, but his quest for justice, concern for the poor and the ecosystem is second to none. Rightly he has addressed these issues in his writings, but with a different accent. Panikkar gives us the context: Whereas the monks of Sri Ramakrishna Mission in Calcutta chided him for 'over-sentimentalism' and argued "that the meaning of life is not to live on earth more or less comfortably", the mother of the starving child, who has given up hope that the child will not live, and hence wanted only the elder one to survive, did know that our options are just options not miraculous remedies. The underlying presuppositions, perceptions, sense of urgency and even of priorities are different for different people, cultures, etc., and one should not impose one's own model upon others. That is to say, even in the case of "option for the poor" and ecological concern, we need stress the cosmic confidence as the basis:

The cosmic confidence is the conviction, belief, myth, acceptance, experience or even postulate that reality is the ultimate ground we have in order to make some sense of anything, find that life has a certain value, the world a certain consistency, our thinking a certain truth and words a certain meaning. We say "certain" or "some" because we cannot exclude the most disparate interpretations of this sense. The very idea that the world may be in chaos or sheer illusion has meaning only over the background of a cosmic order which we assume in order to negate it. Cosmic confidence arises from the awareness that the universe is a kosmos, [ordered whole] that we are conscious participants in the universe, whatever degree of reality, sense or purpose we may attribute to it. Cosmic confidence constitutes an ultimate background for all our actions and activities ${ }^{44}$.

This long quotation shows that cosmic confidence is a multifarious and constitutive awareness shared by all human persons, not restricted to a field of study or a culture or a religion, etc. In this sense, it is an anthropological invariant. Panikkar would call this the harmony of reality: the invisible and ul-

${ }^{44}$ J. Prabhu, The Intercultural Challenge of Raimon Panikkar, p. 280. 
timate order of universe. "It is the confidence of the cosmos itself, of which we form a part in as much as we simply are" 45 . The cosmic confidence affirms the consistency of the universe, the very source of all our values, and the basic attitude which is at the root of all our thoughts. "Cosmic confidence is not our interpretation of the world. It is that awareness which makes any interpretation possible.... We cannot disclaim a cosmic order without assuming it already. Cosmic confidence is the awareness of this state of affairs. The vedic notion of $r t a$ or cosmic order may be a homeomorphic equivalent of what we are saying" ${ }^{46}$. From this perspective, the option for the poor and concern for the eco-system are valid moral options, but based on the ultimate awareness, namely the cosmic confidence.

Panikkar would argue in the same manner against what he considers surreptitious technocentrism. Two comments would suffice to clarify Panikkar's point: first of all, Panikkar is against technocentrism as the universal panacea; it is one viable alternative among many others. By making technology as the solution for every problem, we are re-introducing the monomorphism of a western colonialist attitude; other cultures need be taken as equal partners in solving the issues. Second, technology is not identical with techne which is a human invariant. The difference consists in the fact that the second is the product of a particular culture (western) which may not reveal the sensitivities of other cultures. Panikkar illustrates the point by referring to techne as the machine of the first degree, and technology as the machine of the second degree. "The sources of energy of the first-degree machine respect the energy-rhythms of nature. The second-degree machine breaks, through artificial acceleration, the cosmic rhythms of the natural order and utilizes artificial (unnatural) sources of energy which are not renewable" $"$. The symbiosis with nature is lost here. Nature is reduced simply to world "resources" for the profit of the exploiter. Concern for ecology (science of the earth) should take this fact into account; hence Panikkar would prefer the term ecosophy, "which stands for the wisdom of the Earth ... in which Man shares and which Man represents" ${ }^{\text {. }}$. And ecosophy has been part of humanity as evidenced by the Sadhu to whom a visiting American scientist said: 'we have sent a Man to the moon'. And the Sadhu replied: 'do you know the man you have sent?'49

\footnotetext{
45 J. Prabhu, The Intercultural Challenge of Raimon Panikkar, p. 281.

${ }_{46}$ Ibid.

47 J. Prabhu, The Intercultural Challenge of Raimon Panikkar, p. 288.

48 J. Prabhu, The Intercultural Challenge of Raimon Panikkar, p. 287.

${ }^{49}$ See Panikkar's comments at: "Religions and Cultures in the Indic Civilization".
} 
The emerging consciousness of India: In all these various considerations on Panikkar's thought, we have not explicitly referred to India, but its influence on his perspectives has been brought out. The present section attempts to elucidate the point a little further taking into consideration one of his earliest presentations on India to the outside world. Two aspects will be of interest to us: the political and religious issues. In a text ${ }^{50}$ published in 1960 Panikkar reflects on democracy in general and its current status in India. After having remarked that the coming of democracy in Europe has been the result of a reaction to the decadence of paternalistic regime and hierarchical structures, Panikkar observes that the situation in India is similar; but if it had the time to organize a revolution it would have been along the lines of Gandhi and Ach rya Vinoba Bhave. However, the Indian democracy would be much more a communalism; it would not have fought for a material equality without dignity. Panikkar's point is that democracy is not a fixed model to be transferred from one culture to another; the Indian democracy would be better modelled after the system of Panchayat, which appeals for unanimity rather than majority, and views power from a more religious than a social perspective. These observations confirm what we have seen in Panikkar's political arguments that no universal model exists. In the same vein Panikkar observes that communism in Asia has a different face: 'India has turned towards communism in its search for a greater social justice ${ }^{, 51}$. And he elaborates: if the justice sought for has to be effective, efficacious and of vital interest, it should be in close relationship with the religious traditions of the people where it implants itself. It should not ignore or discredit the religion sacred to the ancestors and to the earth itself. The source of social justice should spring forth from the depths of Indian life, taking also into account the telluric profundity wherein is immersed the unconscious of the rural population, illiterate but not deprived of wisdom ${ }^{52}$. Although changes in the economic and social spheres are necessary, they should not be brutal, injurious, totalitarian, but guided by prudence, patience, deference etc. so that the values of the common folk be respected and integrated. It is here that Panikkar found a serious deficiency with Indian politics. I quote: « La plupart des politiciens et économistes de l'Inde, en théorie comme en pratique, sont convaincus de la

http://www.indicstudies.org/R\%20Panikkarspeech.pdf The presentation was read at the Conference on Religions and Cultures in the Indic Civilization, held at New Delhi in December 2005.

${ }^{50}$ Lettre sur l'Inde, Tournai, Belgique: Casterman, 1963. The book was originally published in Spanish: La India: gente, cultura y creencias, Madrid: RIALP, 1960.

${ }_{51}^{5}$ Lettre sur l'Inde, p. 39.

52 Lettre sur l'Inde, p. 40. 
supériorité de la civilisation -technique et matérielle- de l'Occident ${ }^{35}$. Is it still the case that the Indian politicians and economists are convinced of the superiority of Western civilisation?

Let us move on to the religious realm. According to Panikkar, even though India defines itself as a secular state (impacted by the secular tendency of Europe), it is a religious nation. And its unity is not based in the politics but a cultural past essentially religious. In a recent (Dec. 2005) talk read on his behalf at a conference in Delhi ${ }^{54}$, Panikkar points out that etymologically the term religion is closer to dharma, and the West has lost its original meaning, and India has the envious chance of recovering the meaning and restoring it to the world. Dharma is that which maintains and sustains the peoples; it is the cosmic order of the entire reality. The Indic spirit includes in the dharma, the ultimate order of he universe and its understanding as human religiousness. In other words, religion implies the consciousness of our manifold and constitutive bonds. A religious person is someone who is conscious of all his connections with the entire universe, aware of all the links which relate a person to the whole reality, a fellow-being of the universe. This Indic notion of religion does not tie religion to any organization, although it implies an institution as a sociological complement. It is incumbent on India, says Panikkar, to preserve and to share this religiosity with the world.

But how? Not from a standpoint of inferiority or of superiority. This is not only because attitudes of inferiority and superiority are politically, psychologically etc. are inappropriate, but also because cultures are incomparable. Each culture has its own parameters. The methodology advocated by Panikkar is homeomorphic equivalence, as we discussed earlier. Cultures are incomparable due to the absence of a common denominator, but they can influence each other and a positive symbiosis can take place. In order that this symbiosis take place mutual understanding is necessary: one understands the other by standing under the spell of the other. And we cannot do this if we do not know and love each other. Love and knowledge -jñana and bhaktishould not be separated; they go together. It is from this perspective that Panikkar tells us that religion and culture belong together and complement each other. They enrich each other mutually: religion gives culture its ultimate meaning, and culture gives religion the language to express itself. Panikkar argues against minimizing religion (as is the case in the Western culture) and inflating it (as is often done in India). Neither would contribute

\footnotetext{
${ }_{54}^{53}$ Lettre sur l'Inde, p. 45.

54 See note 49.
} 
to the plenitude of Man. A synthesis - a middle way- is that proposed by the advaita, and it is India's turn to live up to the challenge coming from its own heritage. By successfully meeting this challenge, India would offer a model to humanity in reaching the fullness of Man.

\section{Conclusion}

This concrete challenge of Panikkar --to effect a synthesis between East and West, culture and religion, etc.- is also the result of his view of history comprising of three kairological moments: the pre-reflective awareness (ecstatic moment); humanistic or economic awareness (enstatic moment), and the cosmotheandric awareness. Whereas non-differentiation characterizes the first, discrimination is the hallmark of the second; in the third holistic stage one maintains the distinctions of the second moment without forfeiting the unity of the first. The realization of this vision constitutes for Panikkar the challenge of the third millennium for which India is better equipped.

But let us not forget that this is a vision already partially spelt out (and from a different perspective) in the Renaissance by Marsilio Ficino, when he describes the universe consisting of five elements and Man occupying its center. Thanks to this unique role, Man could be described as vinculum mundilink between the worlds. And for Ficino, Man was enabled to act as a link thanks to ratiocinatio, the discursive reason, which links pure thought and feeling. One should not hence wonder why Panikkar in all his writings, while criticizing reason, showers praises on ratiocinatio, the unique capacity of Man to think holistically. In recuperating ratiocinatio, Panikkar sees the possibility of realizing a new pattern of thought, and hence he calls for a new innocence ${ }^{55}$.

Panikkar is well aware that even the very idea of new innocence is problematic. He writes: "Innocence is innocent precisely because once spoiled, it cannot be recovered. We cannot go back to the earthly paradise, much as we might long to do so. The desire itself is the greatest threat, just as the longing for nirvana is the main obstacle to its attainment. ... The third moment is a conquest, the difficult and painful conquest of a new innocence". For: "We are forced to overcome knowledge by non-knowledge, by a leap of ... faith, con-

55 See his article : "The New Innocence," Cross Currents 27.1 (1977) 7-15; also: Carmen Font, "The New Innocence -Interview with Raimon Panikkar", Share International, n. 8, 1996 (http://www.shareintl.org/archives/religion/rl_cfnew-innocence.htm). 
fidence, feeling, intuition. In other words, the new innocence resides in overcoming the intellectual despair that ensues when we discover that we cannot break out of the vicious circle either by an act of the intellect or by sheer willpower. If we consciously try to overcome the intellectual huit-clos by an act of will, it is still the intellect which directs and inspires us. ... The new innocence ... remains in the antariksa, in the metaxu, the in-between, the positive middle, the ayus, the aion, the saeculum, the world of tempiternal life, neither dreading the realm below nor lured by the kingdom above"56.

Has Panikkar empowered us for this conquest, for this leap? Or has he only indicated the target or the way?

Peter Pandimakil, OSA Estudio Agustiniano -Valladolid Saint Paul University - Ottawa

${ }^{56}$ The Cosmotheandric Experience, pp. 50-51. 